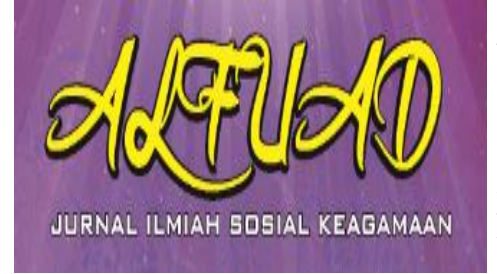

ALFUAD JOURNAL, 4 (1), 2020, (1-11)

(E-ISSN 2714-7606 P-ISSN 2614-4786 )

Available online at

http://ecampus.iainbatusangkar.ac.id/ojs/index.php/alfuad

\title{
IMPLEMENTASI MASYARAKAT TERHADAP PENAFSIRAN SURAT AL-QADR
}

\section{Mutiara Tri Julifa *) \\ Universitas Islam Negeri Imam Bonjol \\ Padang, Sumatera Barat, Indonesia \\ E-mail: mutiarajulifa@gmail.com}

\section{Hafizzullah}

Institut Agama Islam Negeri Batusangkar, Sumatera Barat, Indonesia

E-mail: hafizullah@iainbatusangkar.ac.id

*) Corresponding Author

\begin{abstract}
Departing from a custom that exists in the community of Bukit Putus in Linggo Sari Baganti Subdistrict, Pesisir Selatan District, namely the implementation of Lailatul Qadr circumcision prayer on every twenty-seventh night of the month of Ramadan. This research is called the Living Qur'an Study which is a qualitative field research, using descriptive analysis methods, with data collection techniques through interviews and documentation. The results of the study are the first, the public understands the Laylat al-Qadr prayer as circumcision prayer which is performed to welcome and respect the Laylat al-Qadr. Secondly, the public praying at the end of the twenty-seventh night after completing the evening prayer in congregation. Third, the implementation of the Prayers of Laylat al-Qadr by the community aims to get merit and forgiveness from God. Then the benefits felt by the community after performing lailatul qadr prayers include peace and tranquility of the heart.
\end{abstract}

Keywords: Shalat, Lailatul Qadr, Living Quran

\section{PENDAHULUAN}

Al-Qur'an sebagai petunjuk bagi umat manusia secara umum dan bagi umat Islam secara khusus telah mengabadikan peristiwa satu malam yang lebih baik dari seribu bulan itu atau yang lebih masyhurnya di kalangan umat Islam disebut sebagai malam lailatul qadr. Sebagaimana firman Allah:

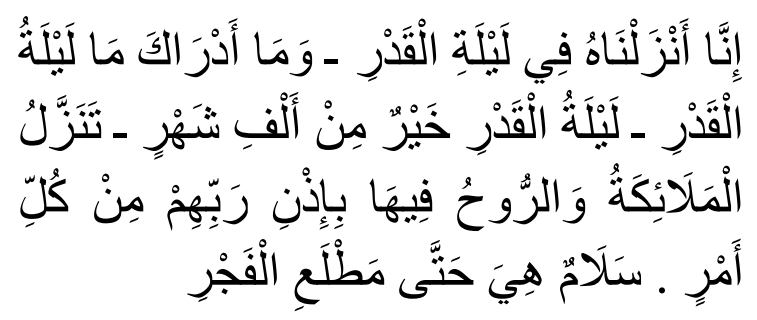

"Sesungguhnya Kami telah menurunkannya (al-Qur'an) pada malam kemuliaan. dan tahukah kamu apakah malam kemuliaan itu?
Malam kemuliaan itu lebih baik dari seribu bulan. Pada malam itu turun malaikatmalaikat dan malaikat Jibril dengan izin Tuhannya untuk mengatur segala urusan. Malam itu (penuh) kesejahteraan sampai terbit fajar”. (Q.S.al-Qadr :1-5)

Malam lailatul qadr merupakan malam yang sangat istimewa dengan kebaikan lebih baik dari seribu bulan dan ganjaran yang besar yang belum pernah didapatkan sebelumnya bagi orang yang menghidupkan malam tersebut. Dengan demikian, umat Islam akan berlomba-lomba untuk melakukan kebaikankebaikan atau ibadah-ibadah sunnah untuk mendapatkan kemuliaan lailatul qadr.

Rasulullah SAW menjelaskan bahwa lailatul qadr itu ada pada bulan Ramadhan 
yakni pada sepuluh malam terakhir tepatnya di malam-malam ganjil. Dengan demikian tidak seorang pun yang dapat mengetahui kapan turunnya lailatul qadr. Sementara praktik yang tampak pada masyarakat Bukit Putus Dalam, yang terdapat di Kecamatan Linggo Sari Baganti, Kabupaten Pesisir Selatan, Provinsi Sumatera Barat, adalah mereka mengkhususkan suatu ibadah sunnah untuk menyambut lailatul qadr yang disebut sebagai shalat sunnah lailatul qadr.

Dalam tulisan ini, penulis akan mencoba menggambarkan bagaimana pemahaman masyarakat kampung Bukit Putus Dalam, Kecamatan Linggo Sari Baganti, Kabupaten Pesisir Selatan, Sumatera Barat, terhadap pelaksanaan shalat lailatul qadr, bagaimana prosesi pelaksanaan shalat lailatul qadr oleh masyarakat Bukit Putus Dalam, dan apa tujuan dan manfaat pelaksanaan shalat lailatul qadr oleh masyarakat Bukit Putus Dalam tersebut.

\section{METODE}

Living Qur'an adalah teks al-Qur'an yang hidup dalam masyarakat dan disebut dengan The Living Qur'an, maksudnya adalah respon masyarakat terhadap teks-teks al-Qur'an dan hasil penafsiran seseorang termasuk di dalamnya respons masyarakat atau resepsi mereka terhadap teks tertentu dan hasil penelitian tertentu (Ahisma-Putra, Mei 2012).

Maka dalam penelitian ini penulis menggunakan teknik penelitian lapangan (field reaserch) dengan pendekatan deskriptif. Metode deskriptif adalah penjelasan fenomena secara akurat yang ditemukan di lapangan, hal ini didasarkan atas pertimbangan dalam penelitian ini yang mencakup tentang segala peristiwa dan kejadian yang sebenarnya terjadi di lapangan ketika penelitian dilakukan.

Penelitian ini dilakukan di kampung Bukit Putus Dalam, Kecamatan Linggo Sari Baganti Kabupaten Pesisir Selatan, Sumatera Barat, yang dimulai dari semenjak penulis pertama kali melakukan observasi yakni pada saat Ramadhan 1440 H sekitar bulan Juni tahun 2019 lalu.

\section{HASIL DAN PEMBAHASAN}

\section{Living Quran}

\section{Pengertian Living Quran}

Menurut bahasa Living Qur'an terambil dari kata Living dan al-Qur'an. Kata Living merupakan bahasa Inggris yang memiliki arti ganda yakni yang hidup dan menghidupkan. Sedangkan dalam istilah bahasa Arab dikenal dengan al-hayy dan ihya (Hasbillah, 2019). AlQur'an berarti bacaan atau sesuatu yang dibaca secara berulang-ulang dalam bentuk mushaf.

Sedangkan menurut istilah ilmu living Qur'an berarti ilmu yang mengkaji tentang praktik al-Qur'an atau mengkaji al-Qur'an dari sebuah realita bukan dari idea yang muncul dari penafsiran teks al-Qur'an. Selain itu dapat juga bermakna sebagai cabang ilmu yang mengkaji gejala-gejala al-Qur'an di masyarakat. Gejala-gejala tersebut dapat berupa benda, perilaku, nilai, budaya, tradisi dan rasa. Dengan begitu kajian living Qur'an merupakan suatu upaya untuk memperoleh pengetahuan yang kokoh dan meyakinkan dari suatu budaya, praktik, tradisi, ritual, pemikiran atau perilaku hidup yang ada di masyarakat 
yang diinspirasi dari sebuah ayat al-Qur'an (Hasbillah, 2019).

Living Qur'an bermula dari fenomena Qur'an in Everiday life yakni makna dan fungsi al-Qur'an yang ril dipahami dan dialami masyarakat muslim (Yogyakarta, 2007). Sebelumnya kajian ini bukan termasuk objek studi bagi ilmu-ilmu Qur'an konvensional (klasik). Tetapi fenomena ini embrionya sudah ada sejak masa dini dalam sejarah Islam namun bagi dunia muslim saat itu belum terkontaminasi oleh berbagai pendekatan ilmu sosial kultural yang membayang-bayangi kehadiran al-Qur'an sehingga tidak mendapat porsi sebagai objek studi.

Tampaknya studi Qur'an lahir dari paradigma ilmiyah murni, diawali oleh studi Qur'an non muslim. Bagi mereka banyak hal yang menarik di sekitar al-Qur'an di tengah kehidupan muslim yang berbentuk fenomena sosial. Model studi yang menjadikan fenomena yang hidup di tengah masyarakat muslim terkait dengan Qur'an sebagai objek studinya. Hanya fenomena sosial muncul karena kehadiran al-Qur'an maka kemudian diinisiasikan ke dalam wadah studi Qur'an, maka dikenal dengan istilah Living Qur'an.

Studi Living Qur'an adalah kajian atau penelitian ilmiah tentang berbagai peristiwa sosial terkait dengan kehadiran al-Qur'an atau keberadaan al-Qur'an di sebuah komunitas muslim tertentu. Dari sana pula akan terlihat respons sosial (realitas) komunitas muslim untuk membuat hidup dan menghiduphidupkan al-Qur'an melalui sebuah interaksi yang berkesinambungan. Dengan pergertian seperti ini, maka dalam bentuknya yang paling sederhana, The Living Qur'an tersebut pada dasarnya sudah sama tuanya dengan Qur'an itu sendiri (Ahisma-Putra, Mei 2012).

\section{Arti Penting Kajian Living Qur'an}

Kajian di bidang Living Qur'an memberikan kontribusi yang sangat signifikan bagi pengembangan wilayah objek kajian Qur'an. Selama ini ada kesan bahwa tafsir dipahami harus berupa teks grafis (kitab atau buku) yang ditulis oleh seseorang, maka makna tafsir bisa diperluas.

Arti penting Living Qur'an adalah memberikan pradigma baru bagi pengembangan kajian Qur'an kontemporer. Studi Qur'an tidak hanya berkisar pada wilayah kajian teks, namun pada wilayah Living Qur'an ini kajian tafsir akan lebih banyak mengapresiasi respon dan tindakan masyarakat terhadap kehadiran Qur'an (Yogyakarta, 2007).

Perlunya kajian al-Qur'an dalam pengertian yang lebih luas yakni "The Living Qur'an". Al-Qur'an tidak hanya dimaknai sebagai sebuah kitab suci, tetapi sebuah kitab yang isinya terwujud dalam kehidupan seharihari. Dengan demikian studi al-Qur'an akan mencakup kitab dengan berbagai macam tafsirnya, tetapi upaya untuk merealisasikan tafsir-tafsir tersebut dalam kihidupan yang nyata dan lingkungan alamnya.

The Living Qur'an adalah ungkapan yang tidak asing lagi bagi kebanyakan orang Islam. Pertama ungkapan tersebut bisa bermakna Nabi Muhammad SAW dalam arti yang sebenarnya, yaitu sosok Nabi Muhammad 
SAW, karena menurut keyakinan umat Islam akhlak Nabi adalah al-Qur'an. Dalam kitab tersebut dikatakan bahwa pada diri Nabi Muhammad SAW terdapat contoh yang baik.

Kedua, ungkapan tersebut memacu pada suatu masyarakat yang kehidupan sehariharinya menggunakan al-Qur'an sebagai kitab petunjuknya. Mereka hidup dengan mengikuti perintah yang terdapat dalam al-Qur'an dan menjauhi hal-hal yang dilarang di dalamnya, sehingga masyarakat bisa seperti al-Qur'an yang mewujud dalam kehidupan sehari-hari mereka.

Ketiga, ungkapan tersebut juga dapat berarti bahwa al-Qur'an bukan hanya sebuah kitab tetapi sebuah kitab yang hidup yaitu perwujudannya dalam kehidupan sehari-hari begitu terasa nyata, serta beranekaragam, tergantung kepada bidang kehidupannya (Ahisma-Putra, Mei 2012).

\section{Pendekatan Living Quran}

Adapun pendekatan-pendekatan dalam mempelajari tentang Living Qur'an di antaranya (Ahisma-Putra, Mei 2012):

Pertama, Paradigma Akulturasi

Paradigma akulturasi menurut Heddy Shri Ahisma merupakan sebuah langkah atau proses yang terjadi ketika kebudayaan tertentu dengan kebudayaan yang lain, kemudian mengambil sebagian unsur-unsur budaya baru kemudian mengubahnya, sehingga budaya baru tersebut terlihat seperti budaya sendiri.

Penelitian ini bertujuan untuk mengetahui terhadap unsur-unsur budaya lokal yang mempengaruhi pola pemikiran atau pemahaman terhadap al-Qur'an baik masyarakat tersebut tidak mengerti atau tidak mengetahui dengan budaya tersebut dan bagaimana ajaran-ajaran dalam al-Qur'an kemudian menjadi unsur-unsur budaya lokal.

Kedua, Paradigma Fungsional

Paradigma fungsional merupakan fungsi untuk mengetahui atau melihat gejala-gejala sosial budaya. Fungsi ini bisa dikatakan dengan fungsi sosial dan fungsi kultural. Misalnya pemaknaan terhadap surat-surat atau ayat tertentu, sehingga mendatangkan atau mencerminkan perilaku tertentu dan fungsional tertentu.

Peneliti bisa juga mengungkap atau mengetahui tentang fungsi-fungsi sosial kultural yang terdapat dalam al-Qur'an itu sendiri. Dengan demikian ayat-ayat yang diyakini mempunyai kasiat tertentu biasanya akan mendapatkan perlakuan yang sangat berbeda dengan ayat-ayat yang mungkin tidak dihafal, akan tetapi ditulis pada sehelai kain putih, minyak misik dan za'faran.

\section{Ketiga, Paradigma Struktural}

Tujuan dari paradigma struktural ini untuk mengetahui dan mengungkap gejala-gejala sosial budaya yang dipelajari sehingga membangun sebuah model yang akan membuat peneliti memahami gejala-gejala yang dipelajari. Adapun peneliti memungkinkan untuk melihat sebagai fenomena dalam pemaknaan al-Qur'an dari suatu struktur tertentu. Dapat juga dikatakan bahwa al-Qur'an merupakan kitab yang dipandang salah satu perwujudan dari sejumlah perwujudan yang lain yang kongkrit seakanakan ada dibalik al-Qur'an. 
Keempat Paradigma Fenomenologi

Paradigma fenomenologi mempelajari terhadap gejalah sosial budaya yang berusaha untuk mengungkap atau pengetahuan tentang tempat mereka berada. Hal ini menunjukan hal yang penting terhadap pemahaman atau pengetahuan mengenai perilaku manusia dalam kehidupan sehari-hari.

Fenomenologi yang digunakan dalam penelitian ini tidak lagi menilai tentang benar atau salahnya pemahaman masyarakat terhadap al-Qur'an. Peneliti mencoba mengungkapkan misanya pandangan atau pemahaman masyarakat terhadap dispensasi puasa Ramadhan, pandanagan masyarakat terhadap surat yasin, dan pandangan masyarakat terhadap pengobatan dengan menggunakan ayat-ayat al-Qur'an.

Kelima, Paradigma Hermeneutik

Pradigma hermeneutik merupakan dalam bentuk teks, Dalam artian gejala sosial budaya yang menggunakan teks, gejala ini terbentuk sejumlah simbol-simbol. Oleh karena itu gejala sosial tidak sama dengan teks. Kajian semacam ini akan muncul pemaknaan atau penafsiran baru yang berasal dari peneliti terhadap pemaknaan al-Qur'an dalam berbagai budaya atau ritual.

Tafsiran yang dikemukakann oleh peneliti tidak mesti sama dengan penafsiran yang dikemukakan oleh masyarakat yang akan diteliti, karena peneliti memiliki data-data yang cukup banyak dari warga yang akan diteliti tersebut. Hal ini merupakan penafsiran atau pemahaman yang berbeda ketika peneliti menemui fenomena-fenomena di lapangan.

\section{Pemahaman Masyarakat Bukit Putus Dalam terhadap Pelaksanaan Shalat Lailatul Qadr}

\section{Sejarah Pelaksanaan Shalat Lailatul Qadr}

Pelaksanaan shalat lailatul qadr oleh masyarakat Bukit Putus Dalam kecamatan Linggo Sari Baganti kabupaten Pesisir Selatan sudah tercatat semenjak dahulunya dari generasi nenek moyang mereka. Umumnya masyarakat yang ada di kenagarian Lagan Hilir Punggasan termasuk salah satunya di kampung Bukit Putus Dalam melakukan shalat lailatul qadr yang merupakan kebiasaan dan tradisi yang diwarisi dari nenek moyang mereka.

Menurut sejarahnya ada seorang tokoh yang membawa ajaran Islam dari Pariaman ke Pesisir Selatan yang bernama buya Sungguah. Buya Sungguah tersebut menyebarkan ajaran Islam di sepanjang Pesisir Selatan termasuk salah satunya ke nagari Lagan. Beliau mulai turun di daerah Aia Batu Balai Selasa dengan mengajar mengaji di surau-surau dan sampai ke nagari Lagan dimulai tahun 1965-1975. Di nagari Lagan ajaran beliaupun diwarisi oleh ayahnya alm. Bapak Sirajuddin Zar kemudian juga diwarisi oleh Buya Tondat dan diajarkan ke generasi-generasi berikutnya seperti alm. Imam Sabuak, alm. ayek (kakek) Ibrahim atau Rahim yang biasa dipanggil masyarakat sekitar.

Setelah itu ada Imam Mulis, Buya Kasim sampai ke generasi saat ini salah satunya imam Buyuang Labai yang berusia 61 tahun. Imam Buyuang Labai dipercaya oleh masyarakat sebagai seorang yang 'alim di kampung Bukit Putus Dalam (Y, 2019). Ini sebagian pendapat yang disebutkan oleh beberapa masyarakat 
Bukit Putus Dalam dari hasil wawancara yang telah penulis lakukan.

Berdasarkan wawancara yang telah penulis lakukan diperoleh informasi bahwa masyarakat menjadikan shalat lailatul qadr sebagai sebuah kebiasaan dan tradisi sehingga shalat lailatul qadr merupakan shalat sunat utama pada bulan Ramadhan yang sangat dinanti kedatangannya untuk dilakukan bahkan dikatakan wajib untuk kerjakan (Gusman, 2019).

\section{Pemahaman Masyarakat atau Jama'ah Bukit Putus Dalam tentang Shalat Lailatul Qadr}

Menurut beberapa pendapat yang penulis dapatkan melalui wawancara mengenai pemahaman jama'ah dan masyarakat tentang shalat lailatul qadr itu sendiri. Salah satunya imam dari pelaksanaan shalat lailatul qadr di kampung tersebut yang bernama bapak Buyuang Labai mengungkapkan bahwa shalat lailatul qadr merupakan perintah Allah berdasarkan Q.S al-Qadr. Dinamakan shalat lailatul qadr karena berdasarkan pada firman Allah tersebut.

Para alim ulama dahulunya memaknai shalat lailatul qadr itu sebagai shalat yang dilakukan untuk menyambut kedatangan lailatul qadr. Selain dengan melakukan shalat yang dinamakan dengan shalat lailatul qadr juga boleh melakukan hal lainnya seperti membaca al-Qur'an, bertahlil, bertahmid dan lainnya. Melihat jama'ah yang begitu banyak maka diadakanlah shalat lailatul qadr oleh orang tarekat secara berjama'ah di kala itu (Labai, 2019). Bapak Buyuang Labai sendiri adalah seorang pengikut tarekat yakni Tarekat Sattariyah.

Kemudian wawancara dengan bapak Lumas Y (Y, 2019)sebagai jama'ah yang aktif setiap tahunnya melakukan shalat lailatul qadr di kampung Bukit Putus Dalam tersebut menjelaskan:

"Pemahaman tu betu nan kito umat Islam waktu bulan puaso kan banyak melakukan sunat, apobilo kito malaksanakan sunat tu banyak kito mandapek amal, jadi lailatul qadr tu kito banyak mambaco Astaghfirullah Alhamdulillah Allahu akbar, jadi lebiah banyak kito kiajon lebih baik kito dapek amal".

Bahwa shalat lailatul qadr itu merupakan shalat sunat untuk menambah amal ibadah di bulan Ramadhan, semakin banyak melakukan sunat semakin banyak pula amal ibadah yang didapatkan karena dalam shalat lailatul qadr terdapat pembacaan istighfar, bertakbir, tahlil dan tahmid sebanyak-banyaknya.

Menurut jama'ah lainnya (Gusman, 2019), menyatakan bahwa:

"Shalat lailatul qadr tu shalat yang lebih baik dari seribu bulan jadi kalau dapek awak mangarajon nyo satiok tahun paling kurang sakali saumua hiduik wak mandapekkan malam lailatul qadr tu".

Pemahaman beliau tentang shalat lailatul $q a d r$ adalah shalat yang lebih baik dari pada seribu bulan. Menurut beliau juga seharusnya setiap orang mengerjakan shalat tersebut setiap tahunnya paling tidak sekali seumur hidup bisa mendapatkan malam lailatul qadr dengan melakukan shalat lailatul qadr tersebut. 
Motivasi Pelaksanaan Shalat Lailatul Qadr oleh Masyarakat Bukit Putus Dalam

Beberapa motivasi masyarakat atau jama'ah melakukan shalat sunat lailatul qadr adalah:

Berdasarkan wawancara bapak Sarjono (Sarjono, 2019) yang menjadi motivasinya melakukan shalat lailatul qadr adalah:

"Memotivasi untuk melaksanakan shalat lailatul qadr salah satunya besar harapan kita bahwa Allah memberikan bonus atau hadiah ibadah yang bukan main besarnya dibandingkan shalat sunnat yang lainnya. Jadi kalau kita betul-betul melaksanakan tepat pas pada malam lailatul qadr tersebut barangkali umur kita tidak akan sampai pada delapan puluh tiga tahun, jadi besar harapan kita kalau bertemu dengan malam lailatul qadr".

Motivasi bapak Sarjono dalam melakukan shalat lailatul qadr adalah untuk mengharapkan bonus yang begitu besar dari Allah SWT.

Berdasarkan wawancara dengan salah seorang pemuda (Apriadi, 2019) yang menjadi motivasinya melakukan shalat lailatul qadr adalah:

"Motivasi nya tu ingin berubah lebih baik dan mencari amal untuk akhirat".

Kemudian wawancara dari salah seorang pengurus masjid (Asmiro, 2019) yang menjadi motivasinya dalam melakukan shalat lailatul qadr adalah:

"Yang mendorong itu ya kebaikan yang akan kita dapatkan dari Allah seperti kebaikan yang lebih baik dari pada seribu bulan itu seperti apa, kita kan ndak bisa mengumpamakan seperti apa, cuman ya kalau kita mau ya kita laksanakan seperti itu."

Bahwa adanya kebaikan yang akan didapati dan kebaikan itu lebih baik dari seribu bulan. Dimana tidak ada seorang pun yang mengetahui bagaimana bentuk kebaikan tersebut maka dengan begitu menjadi pendorong baginya untuk melakukan shalat lailatul qadr.

\section{Prosesi Pelaksanaan Shalat Lailatul Qadr oleh Msyarakat Bukit Putus Dalam Kecamatan Linggo Sari Baganti Kabupaten Pesisir Selatan}

\section{Waktu Pelaksanaan Shalat Lailatul Qadr}

Masyarakat melakukan shalat lailatul qadr pada malam ke dua puluh tujuh Ramadhan setelah selesai pelaksanaan shalat isya secara berjama'ah. Tahun sebelumsebelumnya masyarakat menunggu hingga larut malam dalam pelaksanaan shalat lailatul $q a d r$ namun lima tahun belakangan ini tidak lagi menunggu hingga larut malam disebabkan kondisi jama'ah yang tidak memungkinkan untuk terlalu berlama-lama dalam menunggu larut malam.

Waktu menunggu dimanfaatkan dengan adanya penyampaian dari imam kepada jama'ah perihal tata cara pelaksanaan shalat lailatul qadr atau dalam istilah lainnya maulang-ulang kaji. Sehari sebelumnya imam atau pengurus masjid juga telah mengingatkan kepada jama'ah bahwa untuk hari esoknya akan ada pelaksanaan shalat lailatul qadr. Ketika itu juga disampaikan dan diajarkan kembali kepada jama'ah tentang tata cara pelaksanaannya. Setelah sampai beberapa menit atau paling lama setengah jam imam langsung berdiri mengambil posisi sebagai imam dan melanjutkan untuk pelaksanaan shalat lailatul qadr tersebut. 
Berdasarkan wawancara dari beberapa jama'ah tentang prosesi pelaksanaan shalat lailatul qadr dalam hal ini menurut salah seorang pengurus masjid saudara Boni Asmirol (Asmiro, 2019) yang senantiasa mengikuti pelaksanaannya menyatakan:

"Setelah shalat Isya kita langsung melaksanakan shalat lailatul qadr dan diakhiri nanti dengan shalat tarwih pada malamnya dan langsung witir. Jadi pelaksanaannya setelah shalat Isya. Karena tidak ada anjuran yang lebih detail lagi. Boleh jam 12 malam, jam 1 malam jam 3 malam, cuma kita berdasarkan kepada situasi dan kondisi dan kesehatan dari pada jama'ah kita makanya kita mengambil suatu keputusan di dalam kampung kita setelah shalat Isya kita lanjut shalat lailatul qadr. pelaksanaannya cuma satu kali setahun pas pada malam ke dua puluh tujuh, raka'atnya empat langsung satu salam karena identiknya lailatul qadr itu pas malam dua puluh tujuh makanya kita laksanakan pada malam dua puluh tujuh itu".

Menurut jama'ah lainnya yaitu ibu Idar (Idar, 2019) menyatakan:

"Nan sariang di masajik awak ko di malam duo puluah tujuah, karano tu malam ganjil kecek guru-guru tu, tapi nan acok dilakuan malam duo tujuah, ado e malam duo limo. Dalam bulan puaso sakali nye Ma yo betu anjuran sakali dilakuan ne, tapi malam buliah dituka-tuka, tapi malakuan di bulan puaso sakali ne".

Maksudnya bahwa shalat lailatul qadr yang sering dilakukan di masjid adalah pada malam ke dua puluh tujuh karena itu merupakan malam yang ganjil. Ada juga terkadang dilakukan pada malam kedua puluh lima. Di dalam bulan puasa hanya dilakukan sekali saja sebab itu berdasarkan anjuran dari sebelum-sebelumnya. Boleh diganti malam pelaksanaannya tapi tetap dilakukan sekali saja di bulan puasa.

Dapat penulis simpulkan bahwa pelaksanaan shalat lailatul qadr di kampung Bukit Putus Dalam adalah pada malam ke dua puluh tujuh setelah selesai melaksanakan shalat Isya. Dilakukan pada malam ke dua puluh tujuh disebabkan karena sudah menjadi kebiasaan dari dahulunya. Masyarakat sama sekali tidak menganggap bahwa lailatul qadr itu jatuh pada dua puluh tujuh tetapi menurutnya lebih berpeluang pada malam tersebut. Selain itu masyarakat memahami bahwa lailatul qadr itu turunnya pada malammalam ganjil.

\section{Ketentuan dalam Pelaksanaan Shalat lailatul Qadr}

Mengenai ketentuan dalam pelaksanaan shalat lailatul qadr ini berdasarkan hasil wawancara yang penulis dapatkan dari beberapa informan dapat dikelompokkan pada beberapa pembahasan, di antaranya:

\section{Ketentuan Imam dan Jama'ah}

Informan bapak Buyuang Labai (Labai, 2019) sebagai seorang Imam dalam pelaksanaan shalat lailatul qadr mengungkapkan:

"Ndak, nan siapo bisa untuak mambao malaksanakan, kan samo jo sumbayang limo wakatu mah. Tatacaranyo samo jo sumbayang limo wakatu. Imam tu kan berlebih dari pado jama'ah yang partamo ingatannyo yang kaduo kekhusyukannyo nan katigo pangalamanyo. Itu diutamoan tu nan imamnyo."

Ungkap beliau bahwa ketentuan untuk seorang imam adalah seorang yang bisa untuk mengimami dalam artian orang yang punya 
pengetahuan lebih dari pada jama'ah yang kuat ingatan dan khusyuk dalam pelaksanaannya serta yang sudah berpengalaman.

Kemudian informasi dari jama'ah yakni ibuk Idar (Idar, 2019) mengungkapkan:

"Imamnyo mano nan pandai nan acok malakuan nan lah biaso malakukan".

Maksudnya yang menjadi imam dalam pelaksanaan shalat lailatul qadr tersebut adalah orang yang pandai dan sering melakukan dalam artian orang tersebut sudah biasa untuk mengimami.

\section{Tata Cara Shalat Lailatul Qadr}

Dalam tata cara pelaksanaan shalat lailatul qadr penulis mengambil informasi dari wawancara yang dilakukan dengan imam dan jama'ah shalat lailatul qadr di kampung Bukit Putus Dalam, di antara penjelasannya berikut ini:

Menurut bapak Buyuang Labai (Labai, 2019) tatacara pelaksanaannya adalah:

"Nan partamo kito malaksanakan shalat fardhu shalat isya, sasudah tu kito sunat isya sasudah, baru kito sumbayang sunat lailatul qadr, sumbayang lailatul qadr labiah kurang ado satu satangah jam labiah lamo dari pado sumbayang tarwiah sabab kafiat-kafiatnyo lamo. Cubolah, mambaco partamo yie tu cik di banyak de. Ushalli sumbayang e ushalli sunnatan lailatul qadr arba'a rak'atin imaman lillahi ta'ala, aku sumbayang sunat lailatul $q a d r$ ampek raka'at manjadi imam karano Allah. Bacaannyo nan partamo kabirau, tu alFatihah, sudah itu ayat. Ayatnyo alhakumuttakatsur hatta..... sudah itu baru baco kulhuwallah. Kulhuwallah itu sabanyak 15 kali. Untuk raka'at kaduo cando itu yie ndak ado batuka-tuka lai sampai kaampek. Ha beko ditutuik dengan salam. Baru kito baco zikir tadi lay".
Pertama melakukan shalat fardhu Isya kemudian shalat sunat setelah Isya kemudian baru shalat lailatul qadr. lama pelaksanaan shalat lailatul qadr lebih kurang satu setengah jam dan lebih lama dari pada shalat tarwih sebab zikir-zikirnya lama. Awalnya membaca niat dengan bacaan ushalli أصلي سنة ليلة القدر artinya aku shalat lailatul qadr empat raka'at menjadi imam/ makmum karena Allah.

Kemudian pada raka'at pertamanya membaca do'a Iftitah setelah itu al-Fatihah setelah itu membaca ayat al-Qur'an yakni surat at-Takatsur dan dilanjutkan dengan membaca surat al-ikhlas sebanyak 15 kali. Begitu seterusnya sampai raka'at ke empat dan terakhir ditutup dengan salam dan dilanjutkan dengan zikir yang disebutkan tadi.

\section{Tujuan dan Manfaat Pelaksanaan Shalat Lailatul Qadr oleh Masyarakat Bukit Putus Dalam Kecamatan Linggo Sari Baganti Kabupaten Pesisir Selatan}

\section{Tujuan Pelaksanaan Shalat Lailatul Qadr}

Berdasarkan wawancara dengan bapak Arpen (Punggasan, 2019) bahwa yang menjadi tujuan masyarakat dan jama'ah melakukan shalat lailatul qadr adalah:

"Tujuannya mengharapkan pahala yang lebih besar sebab saya nyatakan pada ayat tadi "lailatul qadri khairum min alfi syahri" beramal pada malam itu lebih baik dari pada seribu bulan. Kalau seribu bulan kita hitung dengan tahun Masehi itu sama dengan 83 tahun 2 bulan, cuma dia satu malam beramal pahalanya dia dapati sama dengan 83 tahun. Dengan syarat dia mendirikan shalat kalau dia tidak mendirikan shalat wajib, dia melakukan shalat lailatul qadr disana amal ibadahnya tidak dapat diambil walaupun dia dapat malam 
seribu bulan, sebab shalat tu merupakan tiang dari pada agama".

Berdasarkan wawancara dengan bapak Zulkanatra (Zulkarnatra, 2019) yang menjadi tujuannya melakukan shalat lailatul qadr adalah:

"Tujuannya tak lain kita menambah amal perbuatan kita yang sangat besar dari pada shalat-shalat lain".

Berdasarkan wawancara dengan Ibu Idar (Idar, 2019) yang menjadi tujuannya melakukan shalat lailatu qadr adalah:

"Untuak mandapek ampunan tadi tu, tu tujuan etek".

Dapat disimpulkan bahwa tujuan utama masyarakat Bukit Putus Dalam melakukan shalat sunat lailatul qadr adalah untuk mendapat pahala yang lebih besar dari Allah yakni kebaikan yang lebih baik dari seribu bulan berdasarkan ayat al-Qadr yang ketiga لََبَّنَ ألْقَزْر خَبْرُ مِنْ أَلْفِ شَهْرِ mendapatkan ridhoNya, mengharap kebaikan, petunjuk perlindungan, ampunan dan kemudahan yang diterima setelah melakukan shalat tersebut.

\section{Manfaat Pelaksanaan Shalat Lailatul Qadr}

Berdasarkan wawancara dari bapak Sarjono (Sarjono, 2019) manfaat yang dirasakannya adalah:

"Manfaatnya yang pertama sekali ada ketenangan".

Berdasarkan wawancara dari saudara Ipra Gusman (Gusman, 2019) manfaat yang dirasakannya adalah:

"Ketenangan jiwa yang kito rasokan saat itu, nyaman lah gitu ha".
Bahwa manfaat yang dirasakan oleh saudara Ipra Gusman adalah merasakan ketenangan jiwa dan kenyamanan.

Berdasarkan wawancara dari saudara Rudi Apriadi (Apriadi, 2019) manfaat yang dirasakannya adalah:

"Alhamdulillah mungkin ada rezki bagi uda, ado nasib yang agak elok tu ha mungkin ado rasaki agak saketek dapek dek awak gitu ha dengan adanya kita melakukan shalat tersebut".

Dikatakannya adanya rezki yang baik yang didapatkan setelah melakukan shalat sunat lailatul qadr tersebut.

\section{KESIMPULAN}

Berdasarkan hasil penelitian sebelumnya dapat penulis simpulkan sebagai berikut:

Pertama, Pemahaman masyarakat Bukit Putus Dalam Kecamatan Linggo Sari Baganti Kabupaten Pesisir Selatan terhadap pelaksanaan shalat lailatul qadr adalah shalat sunat yang dilakukan untuk menyambut dan menghormati lailatul qadr yang diwarisi dari kebiasaan nenek moyang dahulu berdalilkan pada surat al-Qadr. Shalat lailatul qadr bagi masyarakat merupakan shalat yang ditunggutunggu kedatangannya di bulan Ramadhan dan merupakan shalat yang lebih baik dari seribu bulan juga shalat sebagai pengampunan dosadosa yang telah berlalu. Jauh sebelumnya shalat lailatul qadr sudah dilakukan dan merupakan ajaran yang dibawa oleh buya Sungguah hingga saat ini menjadi tradisi yang terus menerus dilakukan oleh masyarakat. Kedua, Prosesi pelaksanaan shalat lailatul qadr oleh masyarakat Bukit Putus Dalam 
Kecamatan Linggo Sari Baganti Kabupaten Pesisir Selatan adalah diawali dengan adanya penyampaian dari imam kepada jama'ah mengenai tata cara pelaksanaannya atau dalam istilahnya "maulang kaji". Pelaksanaan shalat lailatul qadr rutinitas dilakukan pada malam kedua puluh tujuh setelah selesai melaksanakan shalat Isya secara berjama'ah. Shalat lailatul qadr dilakukan sebanyak empat raka'at dalam satu salam. Setelah selesai salam dilanjutkan dengan bacaan zikir dan ditutup dengan do'a. Kemudian setelah itu baru dilanjutkan dengan pelaksanaan shalat tarwih dan ditutup dengan shalat witir secara berjama'ah. Ketiga, Tujuan utama masyarakat Bukit Putus Dalam melakukan shalat sunat lailatul qadr adalah untuk mendapat pahala yang lebih besar dari Allah, mendapatkan ridhoNya, mengharap kebaikan, petunjuk, perlindungan, ampunan dan kemudahan yang diterima setelah melakukan shalat tersebut. Keempat, Manfaat yang dirasakan adalah ketenangan jiwa, kesenangan, merasa telah diampuni segala dosa, diijabahnya do'a dengan adanya tambahan rezki yang diperoleh setelah melakukan shalat sunat lailatul qadr tersebut.

\section{DAFTAR PUSTAKA}

Ahisma-Putra, H. S. (Mei 2012). The Living Qur'an: Beberapa Perspektif Antropologi. Jurnal The Living Qur'an, Vol. 20, No. 1, 237-238.

Apriadi, R. (2019, November 17). Motivasi Shalat Lailatul Qadar. (M. T. Julifa, Pewawancara)

Asmiro, B. (2019, November 18). Motivasi Pelaksanaan Shalat Lailatul Qadr. (M. T. Julifa, Pewawancara)
Gusman, I. (2019, November 17). Pelaksanaan Shalat Lailatul Qadr. (M. T. Julifa, Pewawancara)

Hasbillah, A. '. (2019). Ilmu Living Qur'anHadis Ontologi, Epistimologi dan Aksiologi (Vol. 1). Banten: Yayasan Wakaf Darus Sunnah.

Idar. (2019, November 19). Waktu Pelaksanaan Shalat Lailatul Qadr. (M. T. Julifa, Pewawancara)

Labai, B. (2019, November 18). Pelaksanaan Shalat Lailatul Qadr. (M. T. Julifa, Pewawancara)

Punggasan, A. W. (2019, November 18). Tujuan Shalat Lailatul Qadar. (M. T. Julifa, Pewawancara)

Sarjono. (2019, November 17). Pelaksanaan Shalat Lailatul Qadr. (M. T. Julifa, Pewawancara)

Y, L. (2019, November 18). Pelaksanaan Shalat Lailatul Qadr. (M. T. Julifa, Pewawancara)

Yogyakarta, D. T. (2007). Metodologi Penelitian Living Qur'an dan Hadis (Vol. 1). Yogyakarta: TH Press.

Zulkarnatra. (2019, November 18). Tujuan Pelaksanaan Shalat Lailatul Qadr. (M. T. Julifa, Pewawancara) 